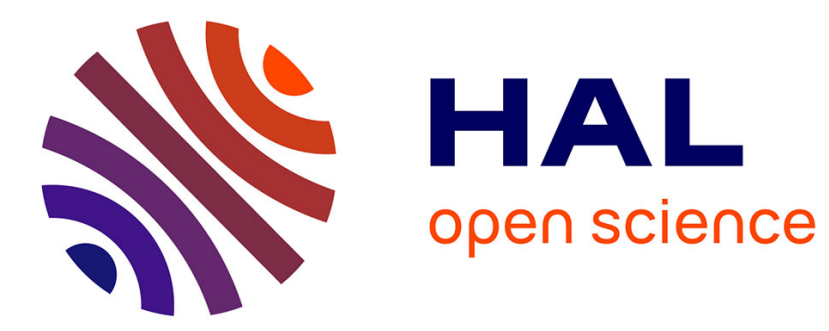

\title{
Effect of level of nitrogen fertilization and protein supplementation on herbage utilization by grazing dairy cows. II. Faecal and urine nitrogen excretion
}

L Astigarraga, Jl Peyraud, M Le Bars

\section{- To cite this version:}

L Astigarraga, Jl Peyraud, M Le Bars. Effect of level of nitrogen fertilization and protein supplementation on herbage utilization by grazing dairy cows. II. Faecal and urine nitrogen excretion. Annales de zootechnie, 1994, 43 (3), pp.714-896. hal-00889031

\section{HAL Id: hal-00889031 https://hal.science/hal-00889031}

Submitted on 1 Jan 1994

HAL is a multi-disciplinary open access archive for the deposit and dissemination of scientific research documents, whether they are published or not. The documents may come from teaching and research institutions in France or abroad, or from public or private research centers.
L'archive ouverte pluridisciplinaire HAL, est destinée au dépôt et à la diffusion de documents scientifiques de niveau recherche, publiés ou non, émanant des établissements d'enseignement et de recherche français ou étrangers, des laboratoires publics ou privés. 


\title{
Effect of level of nitrogen fertilization and protein supplementation on herbage utilization by grazing dairy cows. II. Faecal and urine nitrogen excretion
}

\author{
L Astigarraga, JL Peyraud, M Le Bars
}

\author{
INRA, Station de Recherches sur la Vache Laitière, 35590 Saint-Gilles, France
}

Heavily fertilized grasses led to poor efficiency of $\mathrm{N}$ utilization in cows. This experiment aimed at studying the effect of lowering $\mathrm{N}$ fertilization and feeding protected prctein on $\mathrm{N}$ balance of grazing dairy cows.

Three treatments were compared on perennial rye-grass pasture in a $3 \times 3$ latin square design: $\mathrm{HN}(60-80 \mathrm{~kg} \mathrm{~N} / \mathrm{ha} / \mathrm{growth}), \mathrm{LN}(0-20 \mathrm{~kg} \mathrm{~N})$, and $\mathrm{LN}+\mathrm{S}$ (2 kg soyabean meal (SBM) cow/d). Experimental procedures were described by Peyraud et al (preceding article). The area was increased from 59 (HN) to $72 \mathrm{~m}^{2} / \mathrm{c} / \mathrm{d}$ (LN and $\mathrm{LN}$ $+\mathrm{S})$ to obtain the same herbage allowance $(28 \mathrm{~kg}$ $\mathrm{OM} / \mathrm{c} / \mathrm{d}$ above $7 \mathrm{~cm}$ cutting height) between treatments. $N$ intake was calculated from herbage intake and $\mathrm{N}$ content of grazed herbage. The latter was estimated from bunches of tillers (around $50 \mathrm{~cm}^{2} /$ bunch, 15 bunches per treatment) cut to ground level. A subsample (200 tillers) was extended (cut bases placed together) and cut into $5-\mathrm{cm}$ sections. Those sections lying between the top of the bunches and the mean height of sward after grazing (ie section 20-25 cm) were considered as herbage intake. Urine $\mathrm{N}$ was calculated by difference between intake, and milk and faecal output assuming no $\mathrm{N}$ retention. Ruminal fluid was sampled for ammonia determination between $7 \mathrm{am}$ and $10 \mathrm{pm}$. Blood samples were collected from the caudal vein at 7 am for uremia analysis.

Lowering $\mathrm{N}$ fertilization decreased total $\mathrm{N}$ content in offered herbage from 27 to $19 \mathrm{~g} / \mathrm{kg} \mathrm{OM}$ $(P<0.01)$. N content in grazed herbage was higher because mean residual height after grazing was $23 \mathrm{~cm}$, but the difference still remained between treatments ( $31 \mathrm{vs} 26 \mathrm{~g} / \mathrm{kg}$ OM for $\mathrm{HN}$ and $L N$, respectively) $(P<0.01)$. On $L N$ sward, $N$ intake was lowered, faecal $N$ and milk $N$ output remained unchanged, whereas urine $\mathrm{N}$ output was reduced $(P<0.01)$. Thus, $L N$ treatment reduced $\mathrm{N}$ losses by $25 \%$ per cow and $42 \%$ per unit area compared with HN treatment. These results agreed with the lower ruminal ammonia and blood uremia levels observed in the LN treatment (table I). The SBM supplementation largely increased $\mathrm{N}$ intake but milk $\mathrm{N}$ output was only $14 \mathrm{~g} / \mathrm{d}$ higher. $N$ excretion was notably increased compared with the other treatments $(P<0.01)$. The difference was mainly due to urinary $\mathrm{N}$ flow (table I). However, milk output $\left(0.35 \mathrm{l} / \mathrm{m}^{2}\right)$ and urinary $N$ excretion $\left(4.8 \mathrm{~g} / \mathrm{m}^{2}\right)$ per unit area were similar between $\mathrm{HN}$ and $\mathrm{LN}+\mathrm{S}$ treatment.

$N$ excretion by grazing cows could be manipulated. Lowering $N$ fertilizer is a good way to decrease $\mathrm{N}$ emission per cow. SBM supplementation increased milk yield but also urinary $\mathrm{N}$ output per cow.

Table I. Effect of treatments on $\mathrm{N}$ flows.

\begin{tabular}{lccc}
\hline & $H N$ & $L N$ & $L N+S$ \\
& & & \\
& & & \\
$N$ intake $(\mathrm{g} / \mathrm{d})$ & $503^{\mathrm{a}}$ & $423^{\mathrm{b}}$ & $594^{\mathrm{c}}$ \\
$\mathrm{N}$ milk $(\mathrm{g} / \mathrm{d})$ & $109^{\mathrm{a}}$ & $109^{\mathrm{a}}$ & $123^{\mathrm{b}}$ \\
$\mathrm{N}$ faeces $(\mathrm{g} / \mathrm{d})$ & $113^{\mathrm{a}}$ & $110^{\mathrm{a}}$ & $132^{\mathrm{b}}$ \\
$\mathrm{N}$ urine $(\mathrm{g} / \mathrm{d})$ & $281^{\mathrm{a}}$ & $204^{\mathrm{b}}$ & $340^{\mathrm{c}}$ \\
$(\mathrm{g} / \mathrm{kg}$ milk) & $13.4^{\mathrm{a}}$ & $9.2^{\mathrm{b}}$ & $13.7^{\mathrm{a}}$ \\
$\left(\mathrm{g} / \mathrm{m}^{2}\right)$ & $4.8^{\mathrm{a}}$ & $2.8^{\mathrm{b}}$ & $4.7^{\mathrm{a}}$ \\
& & & \\
$\mathrm{NH} \mathrm{H}_{3}(\mathrm{mg} / \mathrm{l})$ & $189^{\mathrm{a}}$ & $93^{\mathrm{b}}$ & $119^{\mathrm{c}}$ \\
Uremia $(\mathrm{mg} / 100 \mathrm{ml})$ & $25.3^{\mathrm{a}}$ & $15.4^{\mathrm{b}}$ & $25.9^{\mathrm{a}}$ \\
& & & \\
\hline
\end{tabular}

a, b, c Means with different superscripts are different $(P<0.05)$. 